\begin{tabular}{|c|c|}
\hline \multirow{3}{*}{ 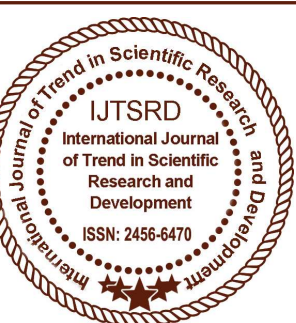 } & $\begin{array}{l}\text { International Journal of Trend in Scientific } \\
\text { Research and Development (IJTSRD) }\end{array}$ \\
\hline & International Open Access Journal \\
\hline & ISSN No: $2456-6470$ | www.ijtsrd.com | Volume - 2 | Issue -3 \\
\hline
\end{tabular}

\title{
Altering Trends in Indian Women in Jhumpa Lahiri's Novel the Lowland
}

\author{
G. Shalini \\ M.A., M.Phil. B.ED, Nadar Saraswathi College of \\ Arts And Science, Theni, Tamil Nadu, India
}

\author{
M. Sheela Devi \\ M.A., English, Nadar Saraswathi College of Arts And \\ Science, Theni, Tamil Nadu, India
}

\begin{abstract}
All these demographic deviations have pretentious the Indian family. Some studies have shown that the Dual household is the idealized pattern, but was never a noticeable marvel in reality. Every family experiences in its life cycle a period when more than two groups, or siblings with their wives and children, live together; but it is a historical phase. With the rising rates of organization, lengthy families are getting disjointed physically. Thus, while family ties remain, the fact of co- home is attainment confined more and more to nuclear families. The women's issues are manifold. They have competed for recognition of their brains, their prowess and their managerial instincts. Women have fought for equal rights in decision making at home as well as in the society, by way of representation in governing bodies. In all these issues, women have identified men to be their antagonists. It is patriarchy, male chauvinism and many more such attitudes of society that women have been considering as hindrance to their growth as individuals.
\end{abstract}

Jhumpa Lahiri has focused on a woman who is not taking up women's issues as her concern. She is merely being herself. Although in the greater part of the narrative, she remains unfocussed about her goals, she is vibrant and decisive about certain steps she takes in the course of her life. For these decisions she takes no one into consideration, consults no one, needs no one's permission or approval, but carries on determinedly out of her own accord, to satisfy her spirit, feeding her instincts and her intellect both by turns. But in doing so she turns out to be a difficult mother.
The children have never been treated as entities directly in conflict with the mother. In Manju Kapoor's Difficult Daughters, we encounter a woman whose sole occupations are reproduction and feeding of her young ones. In her daughter we see a woman who revoluts against this role. She is difficult because she cannot gel with the institutions in a proper, more regulated way. She tries to be an individual but in the course becomes wayward.

In Arundhati Roy's a masterpiece, the acts whimsically when she marries a man from an altogether different community. That is a woman's revolt against societal norms, the dictates of her family and the claustrophobia ensuing from that. In being a woman, in claiming her body as her own and in wandering off at her own sweet will, and in forgetting that her children hang on to her words and her actions for sustenance every step of their growth, she is merely being herself. So she is still a woman at war with the society and harming her beloved children only as a side effect.

A difficult mother is at war with her own child. Gauri in The Lowland sees her child as a burden, a restriction and pushes the child away from her by several maneuvers. She encourages the child to be independent prematurely. She lies to her. She steals time away from her. She plays hide and seek with her and she discourages her attachment to her. She wrings her hand off the clasp of the tender hands of her child. In this way she recognizes the antagonist in her child, rather than in her husband or in the society. She views the child as a binding, ass a bidding 
relation whose wishes are her command and she has to disobey these injunctions to be free, to be herself, to be independent.

\section{"I don't like you, Bela cried out, shaking herself free.}

I'll never like you, for the rest of my life.

She ran ahead. Abandoning her mother on the heels of summoning her.

Not wanting Gauri to accompany her the rest of the way" [TL Pg. No (204)].

On a particular day when her child refuses to go to school Gauri resents it. Another mother might have indulged her... let her stay home, skip a day of school. Another mother, spending the time with her, might not have considered it a waste. The child grows up to offer her free space. Bela is not grown up enough to roam around on her own, but Gauri allows her. It is pathetic to see how the child is deceived about the loveless relationship between her mother and father.

"Every morning she went upstairs, down the short hallway, and knocked on her parents' door to her mother she was leaving (for school), not wanting to disturb her mother but also hoping she'd been heard" [TL Pg. No (247)].

Until one morning she discovers that Gauri actually slept in her study and her father slept alone in the bedroom. It has been observed by critics that the lowland is a reproduction of the atmosphere in Calcutta during the Naxalite Movement of the early nineteen seventies. The novel opens with an acute observation of the life of two brothers, who are intelligent and sensitive individuals. They are good scholars irrespective of their humble upbringing. They pursue their goals independently. They pursue their women too, independently and they treat their feminine partners as equal.

The dominant woman construct in this book is Gauri. She wooed and married by one brother who dies in two years and then the other brother proposes to her that to escape the atmosphere in Calcutta, she should accompany him to America as his wife. In 1972 for a woman to agree to this proposal it is an act of wilfulness. And all her life she avowedly acknowledges that she never loved the second husband. The picture of a selfish woman intensifies when she stays on in this loveless relationship as long as she is a student. The moment she gets a job in a different part of the country, she runs away. She abandons her child and sneaks off leaving only a letter behind.

In India, gratitude is uppermost in a woman's virtue. It may be misconstrued, created by a male dominated society to keep a woman subordinated, inferior as well as humiliated in many ways, but women exalt in being grateful to the man who 'saved' her life or the man who rescued her from distress. Gauri is far from grateful. She only takes advantage.

On the flip side, Gauri is a brilliant scholar. She is rather ashamed of her callousness about family and child but passionately pursues her study of philosophy as well as the independence she has earned through it. She refrains from keeping in touch with professor Otto Weiss who had initiated her into pursuing the doctoral program on Hegel and who used to ask her often how her child was. She avoids the professor so that she does not form a bad impression on him. It has no link to the child as such.

Gauri never enquires about the child's wellbeing. She writes in her farewell letter that she believes that Subhash, its uncle-cum-step-father was the best father it could have got. She even ignores the fact that the child is a daughter on the verge of reaching the age of puberty, a twelve year old girl who needs a mother's guidance most at this time. While Gauri lived in California and he in Rhode Island, Subhash never contacted her.

Gauri is ambitious so far as her passion for philosophy is depicted. It comes to her naturally, as a kind of love, not in the form of rebellion against norms, the Indian society of the 1970s. However, her swift transition from being an Indian wife to an Americanized woman is not associated with her love for philosophy. It is more of an assertion of her detachment from home and in this she actually does not belong either to India or to America.

Gauri's behaviour is explained in the last chapters of the novel. She acts as a woman who has disadvantageously confused her love for her first 
husband and the guilt of having plotted in killing a man, the father of a boy. It was a guilt she shared with her first husband and therefore, when the child of her love is born, she cannot hold her and cry like the woman in Tennyson's memorable poem, Home They Brought Her Warrior Dead with 'Sweet my child, I live for thee'. She is loyal to her first husband both in love and in guilt.

Real life does not allow a human being to cling to the ephemeral past lifelong. The plot of the novel hinges on this prolonged adherence to the past which was a period of about three years in Gauri's life. Compared to that, any human being who has been treated kindly and lovingly by a husband and a child she has born, that too who is by blood the child of the earlier beloved husband, would not fail to reciprocate that kindness and love. She suffers no clash with any authority, no restraints on her movements, no norms to kill her ambition, no husbandly jealously to encounter and still she fails to be a good mother. That is how she turns out to be a difficult mother who refuses to take any responsibility or to sacrifice her ambition for the sake child. The child is her adversary in this novel.

The weakness of the novel also rests on the same hinge. The narrative struggles to sympathize with Gauri but it is ingrained in the art of the novel to betray a deeper truth. It is by far the story of a woman who cannot be sympathized with. An American woman, Holly too takes her child's wellbeing into account regarding every decision she takes. When he recounts to her how frightened his parents were when once as children he and his brother had high fever,

Gauri's daughter, Bela too looks forward to a relationship where her child's happiness would be taken into account. The novel details the difference between the occasional flings to feed the senses and love that involves care and concern. Bela bears the child of a man who had no love to spare. Later on she finds a friendly man as a caring companion. The fine distinction between having parents who love each other and parents who only tolerate each other is drawn in this novel to show that blood ties do not matter for the child. The child loves only those who love it.
Wedged between Holly's attitude and Bela's maternal attitude, Gauri's decisions and actions are unforgivable, irrespective of the episode of the murder of a policeman that comes up later by way of an explanation of her unusual conduct.

Gauri and her lover were involved in an aimless murder of young policeman, only to get him out of the way so as to be able to hide political activists. In doing so, they render his son fatherless. The couple cannot overcome the guilt of this murder. The night following the murder of the policeman, the night before the police killed him, Udayan in fever, says:

'I can't become a father, Gauri... Not after what I've done." [TL Pg. No (394)].

How an Indian woman, who has been late by over a century, compared to the women in America, in growing awareness regarding the injustices that she has been taking for granted, would read this novel is a rather dicey question. Most Indians who are ingrained in the virtues of loyalty and gratitude would click their tongues. Most educated and working women would long to have a husband like Subhash who gives Gauri immeasurable person space. Almost all Indian women who have born children would be appalled by the fact that whoever her husband might be, so long as it is one's own child, there is no possibility of Gauri being callous and irresponsible the way it is depicted in the novel.

In India there is only a small fraction of the Indian society who has suddenly developed this opinion that raising a child is a great responsibility and an ambitious woman does not want to have a baby at all. But this disinclination to bear a child us a growing trends of the present. Jhumpa Lahiri has situated her story in the nineteen seventies and eighties and created the image of a woman who is born Indian but who quickly adopts a western attitude in dress and bearing. Pretty much in a forced hindsight, Lahiri foresees the beginning of this trend. Critically thinking, this miscalculated foresight is perhaps the result of her trying to juxtapose the two themes of the historical Naxalite Movement and the woman's issue.

The God of Small Things is a story based on the same period of the Naxalite Movement. The central conflict is social. It is the story of a union between a 
Touchable and an Untouchable that the society does not permit. The twins with whom the author's empathy is invariable are victims of the punishment their mother suffers in the hands of society. There is no other clash between the mother and the children. They are loved by her lover and them like him very much. They are not represented as burdens on her, nor do they in any way restrict her freedom. Whatever she does, even to gain her freedom, she includes them as part of her. There is no question of a mother wishing or trying to abandon the children. The entire novel receives the sympathy of the reader on account of the various depictions of love in every quarter of the society.

The Lowland, by comparison, depicts calculated love in almost everyone. This is also true of the parents of Subhash and Udayan. They cannot overcome the shock being abandoned by their sons. However, the relationship that triumphs at the end is that of Bela and her step-father Subhash, which is selfless love. It is as if the role which a woman is attempting to relinquish in order to secure her independence is getting into full view. The role is so important that if she abandons it, the father has to take it up immediately. Earlier it could be assumed that the father was more or less an incompetent and less asked for parent. He stayed on the frontiers, guarding the family from the world outside. He loved but expressed it in unfamiliar terms. So the child clung to it mother. It recognized her as the object of its love only because she attended to its daily needs. Now it can be assured that if the father too attends as much to a child, the child is bound to acknowledge his love. This does not basically set the mother free. It only helps the mother in some ways. The tie between the mother and the child is umbilical.

Thus, if a mother severs this tie the child undergoes a trauma, needing psychotherapy as Bela does after Gauri leaves her. Bela returns to her father only after much deliberation. A woman should not refuse to take her position as mother as ordained by nature. In trying to bring gender equality in the society, it is more important for a man to assume many feminine virtues/roles than for a woman to become as thoughtless and detached from home as men are accustomed to be.

It is also a lesson worth remembering that in the animal kingdom too, gender roles are quite divided, as zoologists would validate. It is only human species that have overcome the natural inclinations and handicaps with the help of developed technologies making everyone almost equal in calibre. But then humans have also trapped themselves in expansive philosophies.

It is truly said that unlike animals and birds, human beings have a memory and a forethought that constantly impinge on the present and the memory of bad things as well as evil foreboding always spoil happiness in the present. The Lowland is a remarkable tale of such human behaviour.

Bela was born as daughter of Subhash and Gauri in the United States. She was second generation Indian immigrant in the US. Her name signifies a flower or time in Bengali language. Her name was chosen by her father Subhash. She was born in the month of July to Gauri. The baby was placed in the arms of Subhash, from there; she has given a new life to her father Subhash, who is her uncle. Gauri found it difficult to manage and hold Bela; she even thought all, "mothers needed assistance". She even wanted to hand over her burden to Subhash, because he was not her daughter's biological father. He just took the responsibility of a father. Subhash always remains helpless in his conjugal life. But the child Bela accepted and recognized Subhash's love and care. She found secured and safe under the care of her father, than with Gauri.

This paper focuses on the struggle that a girl child encounters after the mother's unexplained separation. Children are fragile in nature, due to their innocence and immaturity they do not know how to handle the sudden severance of their beloved ones. Even though adults also suffer sudden separation of their loved ones, but they can express their plan and anguish, whereas children are often tongue-tied. They struggle to cope with the mental struggle that they bump into. It is in the hands of the parents to mould the child into a venerable personality in the society. Fortunate children are filled with memorable memories, but unfortunate children, Bela falls under inopportune child who experienced rejection and negation from her mother. Bela's mother Gauri 'lacked moral code' and pointed out Bela as a "Hlost child of two cultures. But Bela's story was abridged". 
It also investigates disharmony and the consistent turbulence and opulence in the mind of the central character, Bela who is torn to pieces by time, truth and negation. She yearns for a maternal bonding but seeks solace in her father, whom she sees her redeemer. Frost rightly remarked, "The Best way out is through". Bela finds harmony after fighting a series of losing battles with her mother, her past and unknown future. But the final harmony dawns not in a jiffy but after going through all perspectives of unrest and unhappiness. In a nutshell, the paper projects Bela's journey of disharmony by going through her destination of harmony.

Bela's biological parents are Udayan and Gauri. Udayan and Gauri's marriages were a love marriage which was not accepted by his mother. Udayan was shot dead by the police due to his involvement in anti-social movement and also for murdering a policeman. Before his death he was not aware of Gauri's pregnancy. Subhash who is Udayan's brother came from the US after his brother's death; they were inseparable during their childhood days. But their vision and ambition were two poles apart so Subhash decided to continue his higher studies in America and Udayan became rebellion in his home land. Subhash married his sister-in-law in order to save her from the ordeal and loneliness she endured in his house after Udayan's death.

When Bela started comprehending things, there was always a contradiction between Bela and her mother. Gauri corrected her daughter's mistakes not as a caring mother but as a stranger. So the little girl '...was frustrated with Gauri for contradicting her'. Because of Gauri's nature of contradicting with her only child, Bela never shared the things that happened in school which other kids put together.

She acted like a grown-up and espoused detachment with her mother and she used to enquire about her father Subhash on his absence. Gauri was not ready to accept Subhash as her daughter's father. This was evident, when she said 'your father's not here'. It carries two meaning. Gauri meant that Bela's father was no more, whereas for Bela Subhash was not there at that moment.

Actually the birth of Bela affected Subhash and Gauri in two different ways. Her birth gave a new meaning to Subhash' life whereas for Gauri it always remained her own recurring past. So whenever she spent time with Bela she always felt desolated and never behaved as a fine and compassionate mother. She always maintained distance from Bela and bequeathed significance to her higher studies to divert her from the haunting past. Gauri fails to apprehend that she is ignoring the incarnation of the future.

In general the birth of a baby gives a new life for a mother and a mother sees things around her with her new born baby. But in Gauri's case, Bela always lingered as an impediment and entrenched past. But Bela was repudiated by her own mother; the child was not old enough to extrapolate her mother's haunting past. As a child Bela also prolonged distance and kept all her information and things to himself. Just like any other child she too played with inanimate things but she communicates with object, the communication that she made with inanimate things was more than the communication between Bela and her mother. At one stage when Gauri shut herself inside room for her research, Bela never disturbed her mother, but she was content with the presence of Gauri around her. She even started doing her work by herself; there was no one to look at

Bela celebrated her 12 th birthday in Calcutta with her father and grandmother, her mother was not there with her she was in America. Gauri even did not call Bela to wish on her birthday. The little girl coveted for her mother's wish but Gauri did not turn up. Gauri from the beginning failed to shower the little girl with unconditional love. Hilary crew in her article on mother-daughter relationship states, A mother's emotional relationship with her daughter is thus considered in relation to the pressing demands of ensuring physical nurturance (crew). When Gauri separated from Bela and Subhash, she moved to California, even then the little girl could view the shade of her mother in their Rhode Island house which remained her Gauri's shadow. It was an association she noticed only after her mother was gone, and was unable thereafter to dispel. The apparition of Gauri was felt by Bela every morning.' It was the sort of spontaneous association one might make while looking up at a passing cloud. But in this case never breaking part, never changing into anything else. At that stage Bela was unaware of the consequences of her mother's separation; she thought 
her mother will visit her soon. "The depiction of Gauri's character is examined in diverse perspectives. Michiko calls Gauri as 'an angry, selfish woman' and 'she comes across not as a flawed and complicated person, but as a folk tale parody of a cold, selfish witch". James Lasdun points out, "her depiction is relevant lessly sole men and insistently -actually infuriatingly- compassionate. Lahiri also wishes to enlist our kindness for Gauri as a mortal of tragic emotive reliability".

\section{Bibliography:}

Bhattacharya, Anuradha. "Difficult Mothers: The Lowland as a Study of Changing Trends in Indian Women." 